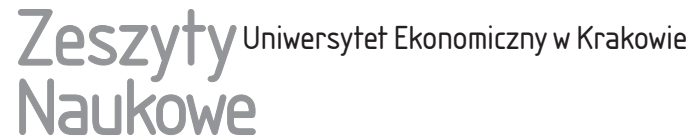

\section{Rafat Lisiakiewicz.}

Katedra Nauk Politycznych

Uniwersytet Ekonomiczny w Krakowie

\section{Miejsce Samoobrony RP w typologii partii politycznych}

\section{Streszczenie}

Samoobrona Rzeczypospolitej Polskiej kierowana przez charyzmatycznego lidera A. Leppera w pierwszym dziesięcioleciu XXI w. była jedną z najciekawszych formacji na polskiej scenie politycznej. Jej sukces oraz upadek należy wiązać z określoną sytuacją polityczną w kraju oraz specyficznym apelem politycznym i sposobem działania ugrupowania. Jednocześnie trudno jednoznacznie sklasyfikować to stronnictwo. W artykule podjęto próbę naświetlenia podstawowych problemów związanych z umiejscowieniem Samoobrony RP w typologii partii politycznych.

Słowa kluczowe: Samoobrona RP, Andrzej Lepper, typologia, partia polityczna, polski system partyjny, populizm.

\section{Wprowadzenie}

Początki Samoobrony sięgają spontanicznego ruchu protestu rolników z Pomorza Zachodniego (okolice Darłowa to rodzinne strony A. Leppera) i Zamojszczyzny, który przerodził się w związek zawodowy. Samo powstanie partii politycznej pierwotnie miało na celu wyłącznie wsparcie odgrywającego przez dłuższy czas rolę pierwszoplanową Związku Zawodowego Rolnictwa „Samoobrona” (ZZR „Samoobrona”). Można zatem wysunąć tezę o charakterystycznym dla systemu partyjnego w Polsce patronacie związku nad partią [Piskorski 2006, s. 156]. 
Jak relacjonował wiele lat później A. Lepper, pomysł stworzenia związku zawodowego, a następnie ruchu politycznego, zrodził się po spotkaniu z wicepremierem L. Balcerowiczem jesienią 1991 r.: ,wszystko, co działo się potem - ze mną i Samoobroną - w jakiejś mierze zawdzięczam zatem tej rozmowie [dwugodzinnej - przyp. R.L.] sprzed 10 lat" [Piskorski 2004a]. W styczniu 1992 r. został zarejestrowany Związek Zawodowy Rolnictwa „Samoobrona”. Partia polityczna, która występowała początkowo pod nazwą Przymierze „Samoobrona”, została natomiast zarejestrowana 12 czerwca 1992 r. W jej skład - oprócz przedstawicieli ZZR „Samoobrona” - weszli również działacze Związku Zawodowego Metalowców i frakcja Zielonych z J. Bryczkowskim na czele (jego obecność stała się potem źródłem napięć i konfliktów w partii). A. Lepper postulował utworzenie szerokiego ruchu społecznego obejmującego ZZR „Samoobrona”, Przymierze „Samoobrona” oraz powoływane w poszczególnych regionach Komitety Samoobrony Narodu [Piskorski 2006, s. 157]. W styczniu 2000 r. dokonano zmiany nazwy z Przymierze „Samoobrona” na Samoobrona Rzeczypospolitej Polskiej [Piskorski 2006, s. 163]. Od śmierci założyciela partii A. Leppera w 2011 r. ugrupowanie przechodzi poważny kryzys swej działalności.

Samoobrona Rzeczypospolitej Polskiej to specyficzna formacja na polskiej scenie politycznej. Na funkcjonowanie tej partii, jej apel ideologiczny oraz program niewątpliwie ogromną rolę wywarła historia jej powstania. M. Piskorski (notabene jeden z ekspertów Samoobrony), posługując się wyróżnionym przez M. Duvergera kryterium klasyfikacji genetycznej partii politycznych, stwierdza, że Samoobrona RP jest partią utworzoną zewnętrznie, tzn. ukształtowanie się pozaparlamentarnego ruchu społecznego poprzedziło jej instytucjonalizację. Początkowo naturalne zaplecze społeczne ugrupowania stanowili rolnicy, stopniowo pozyskało ono jednak inne grupy społeczne, zwłaszcza bezrobotnych i usiłowało przekształcić się w ugrupowanie wyborcze (catch-all party) [Piskorski 2006, s. 167]. Partia A. Leppera reprezentowała typ często spotykany na polskiej scenie politycznej i w innych krajach postkomunistycznych - partię tworzoną „od góry do dołu" [Antoszewski 2008, s. 64].

W niniejszym artykule podjęto próbę określenia miejsca Samoobrony RP w typologii partii politycznych, z zaznaczeniem, że niezmiernie trudno jest precyzyjnie umiejscawiać ją w ramach polskiego systemu partyjnego. Dzieje się tak przede wszystkim dlatego, że sam polski system polityczny jest w znacznej mierze niedojrzały i wykazuje duże tendencje rozwojowe. Trudność ta wiąże się też z faktem krótkiej obecności Samoobrony RP na polskiej scenie politycznej, szczególnie jeśli brać pod uwagę fakt uzyskania reprezentacji w parlamencie (tylko dwie kadencje) [Drelich 2006, s. 102]. W literaturze przedmiotu często podkreśla się, że aby „prawidłowo zakwalifikować konkretny przypadek systemu partyjnego jako odpowiadający danemu typowi czy klasie, musi upłynąć dłuższy 
czas, choć nikt precyzyjnie nie definiuje, co to dokładnie znaczy" [Antoszewski 2002, s. 137].

Najbardziej uniwersalną metodą klasyfikacji partii politycznych jest typologia oparta na interpretowaniu rywalizacji partyjnej na skali lewica-prawica. Kryterium ideologiczno-programowe stało się podstawą klasyfikacji partii politycznych opartej na koncepcji rodzin partii. Mamy tu do czynienia z trzema kryteriami: genetycznym, materialnym i organizacyjnym, przy czym to ostatnie ma charakter pomocniczy. Najistotniejsze jest kryterium materialne, czyli uwzględniające postulaty programowe. Kryterium genetyczne wiąże się z pojawieniem się podobieństw, które ukształtowały się w wyniku zbliżonego procesu instytucjonalizacji [Herbut 2002, s. 153-154]. Inne przydatne dla niniejszych rozważań sposoby klasyfikacji to kryterium funkcjonalne i organizacyjne. Te spostrzeżenia zostaną wykorzystane dla zrealizowania podstawowego celu artykułu - próby pozycjonowania Samoobrony wśród różnych typów partii politycznych.

\section{Samoobrona RP a klasyczne typologie partyjne - podział lewica-prawica}

Umiejscowienie Samoobrony RP na diadzie prawica-lewica i zakwalifikowanie do jednej z rodzin ideologicznych jest niezwykle trudne $\mathrm{z}$ uwagi na jej populizm. Tego typu formacje unikają jawnych deklaracji ideowych, chcąc odwołać się do jak najszerszych grup społecznych i trafić ze swą propagandą polityczną do jak największej rzeszy wyborców. Doskonałym przykładem takiej sytuacji było nazwanie przez samego A. Leppera swego ugrupowania ,socjalno-chrześcijańskim ruchem ludowo-narodowym walczącym o suwerenność Polski” [Migalski 2008, s. 209-210].

Generalnie na skali lewica-prawica Samoobrona RP umieszczana jest po lewej stronie. A. Antoszewski określa nawet Samoobronę RP mianem ugrupowania radykalnej lewicy i zwraca uwagę, że w wielu momentach poprzez akcentowanie konieczności powstrzymania prywatyzacji oraz ochrony narodowych interesów jej postulaty były zbieżne z postulatami partii neokomunistycznych. Argumentem dla badacza za traktowaniem Samoobrony RP jako partii radykalnej było jej miejsce w Parlamencie Europejskim, gdzie wraz z Ligą Polskich Rodzin należała do frakcji niezrzeszonych, obejmujących takie formacje, jak francuski Front Narodowy czy skrajnie nacjonalistyczny Blok Flamandzki [Antoszewski 2008, s. 243]. Z klasyfikacją Antoszewskiego zdaje się nie zgadzać T. Szawiel [2002, s. 205], umieszczając Samoobronę RP na skali lewica-prawica na prawo od SLD i blisko PSL - jako umiarkowaną lewicę. B. Fedyszak-Radziejowska [2005], upraszczając kryteria klasyfikacyjne, określa partię A. Leppera jako strukturę pozbawioną 
tożsamości, choć bazującą przede wszystkim na poparciu elektoratu o poglądach lewicowych (za: [Piskorski 2010b]).

W literaturze anglojęzycznej pojawia się określenie partii kierowanej przez A. Leppera jako radykalnej lewicowo-populistycznej. W związku z klęską wyborczą SLD w 2005 r. Samoobrona RP określana była czasem mianem „,nowej lewicy" [Miliard 2007, s. 211]. Nazywano ją także partią lewicową o populistyczno-agrarnym obliczu [Gwiazda 2008, s. 762].

M. Migalski stara się pozycjonować Samoobronę RP na wykresach rywalizacji lewica-prawica i osiach wartości, rozpatrując jej pozycję na podstawie wyników wyborów do parlamentu z 2001 i 2005 r. Określa on Samoobronę RP jako partię lewicową z tendencjami do ewolucji oblicza ideowo-programowego. Zdaniem badacza w 2005 r. Samoobrona RP zmieniła swój apel ideologiczny w porównaniu z apelem z 2001 r. i w obszarze aksjologii przesunęła się w kierunku partii prawicowych [Migalski 2008, s. 207 i 213]. Wiązać to należy z wymiarem etycznym - partia coraz częściej „,kokietowała” wyborców swym przywiązaniem do tradycji narodowej i kościelnej, a jej przywódca pielgrzymował na Jasną Górę i do parafii św. Brygidy w Gdańsku, potępiał także parady homoseksualne [Migalski 2008, s. 214-215]. Jeszcze pod koniec 2003 r. Samoobrona RP włączyła się do dyskusji nad kwestiami przerywania ciąży i legalizacji związków partnerskich (w tym par homoseksualnych). Uważając je za „tematy zastępcze”, jednocześnie popierała stanowisko Kościoła w tych kwestiach i wyrażała swój negatywny stosunek wobec liberalizacji prawa w tych dziedzinach [Stanowisko Prezydium... 2003]. Zakwalifikowanie Samoobrony RP do jednej z podstawowych rodzin ideologicznych jest zatem niemożliwe; można jedynie stwierdzić, że była to partia typowo populistyczna [Migalski 2008, s. 210].

Na trudność z klasyfikacją Samoobrony RP zwraca uwagę także S. Drelich, pisząc, że z jednej strony partia A. Leppera przedstawiała się jako „prawdziwa lewica", natomiast teoretycy określali ją jako socjalistyczną czy lewicowo-socjalistyczną, co pozwalało jej na zawieranie sojuszy z socjaldemokratycznym Sojuszem Lewicy Demokratycznej. $Z$ drugiej strony obecność treści antyliberalnych i nacjonalistycznych skłaniała ją do współpracy z konserwatywnym Prawem i Sprawiedliwością oraz narodowo-katolicką Ligą Polskich Rodzin [Drelich 2006, s. 103].

Ten swoisty eklektyzm ideologiczny Samoobrony RP wynikał przede wszystkim z jej początków, z charakteru elektoratu, do którego adresowała ona swój apel, ale także w dużej mierze z czynnika osobowościowego kandydatów, którzy znaleźli się na listach wyborczych Samoobrony, a następnie w parlamencie. Oczywiście można także odwrócić tę zależność i stwierdzić, że to właśnie rozmycie ideologiczne Samoobrony powodowało, że na jej listach mogły znaleźć się osoby reprezentujące bardzo barwny konglomerat ideologiczny. Okazuje się, że spośród należących do Samoobrony RP 53 posłów i 2 senatorów z elekcji z 2001 r. 9 nale- 
żało wcześniej do Polskiego Stronnictwa Ludowego, po jednym do Sojuszu Lewicy Demokratycznej, Polskiej Partii Socjalistycznej, Krajowej Partii Emerytów i Rencistów, Forum Emerytów i Rencistów; kilku działało w innych niż ZZR „Samoobrona" organizacjach związkowych - jeden w Solidarności '80, dwóch w Solidarności Rolników Indywidualnych. 36 parlamentarzystów z klubu prowadziło działalność rolniczą, zaś 9 legitymowało się wykształceniem wyższym [Piskorski 2006, s. 184]. Wśród czołowych działaczy partii A. Leppera można było odnaleźć dodatkowo osoby związane wcześniej z Forum Młodych Ludowców, Partią X czy frakcją Zielonych J. Bryczkowskiego. Specyficznym rozwiązaniem statutowym Samoobrony RP była możliwość łączenia członkostwa w partii z członkostwem w innych partiach politycznych. Dopuszczano uzyskanie członkostwa zbiorowego przez inne partie, organizacje związkowe i społeczne. Te dane przekładały się także na program ugrupowania, w którym można dostrzec zarówno wpływy agraryzmu, jak i doktryn skrajnie lewicowych, przy czym apel wyborczy partii i stosowana przez jej kierownictwo retoryka pozwalały na zaliczenie ugrupowania do szeroko rozumianej grupy partii populistycznych. Postulaty ideowo-programowe Samoobrona RP wiązała z tzw. trzecią drogą [Piskorski 2004b, s. 45-46].

\section{Populizm Samoobrony}

Populizm, zarówno „klasyczny”, jak i współczesny, charakteryzuje swego rodzaju „kameleonizm”, co wynika z faktu, że nie istnieje żadna ideologia populistyczna - „są co najwyżej jakiejś na nią zadatki” [Dzwończyk 2006, s. 122]. Według E. Laclaua „,ruchy populistyczne organizują się wokół pewnych symboli i wartości, które same w sobie nie są ani lewicowe, ani prawicowe" (za: [Dzwończyk 2006, s. 122]).

A. Antoszewski i R. Herbut [2006, s. 103] piszą, że osobliwością Europy Środkowo-Wschodniej jest sytuacja, iż nie wszystkie partie polityczne zdolne do wygrywania wyborów i kształtowania polityki państwowej można zaklasyfikować do jednej z klasycznych rodzin partii. Wspólnym mianownikiem dla tego rodzaju partii może być często populizm, rozumiany przede wszystkim jako specyficzny typ apelu wyborczego i stylu uprawiania polityki, a nie jako ideologia. Drugą wspólną cechą tych formacji jest personalizm, który wiązać należy ze szczególną rolą lidera. Do partii populistycznych zaliczają oni właśnie Samoobronę Rzeczypospolitej Polskiej [Antoszewski i Herbut 2006, s. 346].

Większość badaczy z tego zakresu opowiada się za stwierdzeniem, że Samoobrona RP jest przykładem klasycznego ruchu populistycznego na polskiej scenie politycznej. Kwalifikując ugrupowanie polityczne do grona nurtów populistycznych, bierze się najczęściej pod uwagę metody jego działania. M. Marczewska- 
-Rytko za podstawowe kryterium populizmu uznaje stopień zgodności elementów populistycznego kanonu wartości z wizją wynikającą z programu politycznego i podejmowanych kroków w celu jego realizacji. Wyróżnia kilka elementów populistycznego kanonu wartości: odwołanie się do sfery moralności jako podstawy życia społecznego, politycznego i ekonomicznego; idealizację ludu, narodu czy społeczeństwa; antyelityzm; konspiracyjną (spiskową) teorię dziejów; rozwiązanie pozytywne zawarte w postulatach tzw. trzeciej drogi połączone z utopizmem; przywództwo charyzmatyczne; główną rolę podziału na biednych i bogatych w systemie stratyfikacji społecznej [Marczewska-Rytko 2004, s. 258] czy - zgodnie z opinią J. Dzwończyk - dychotomię „panowie”-,,chamy”, co ma być odzwierciedleniem „populizmu protestu” o charakterze plebejskim [Dzwończyk 2006, s. 124].

W kanonie wartości populistycznych pierwszoplanową rolę odgrywa sfera aksjologiczna, a ściślej - moralność. Podstawą działania w populizmie jest zatem wola, a nie kwalifikacje i kompetencje; rządzić może każdy obywatel, który będzie miał uczciwe intencje. Populizm odznacza się nieufnością i niechęcią do polityków i polityki traktowanej jako profesja. Samoobrona RP podkreślała własną czystość moralną, jako że wywodziła się spoza establishmentu, istniejącego układu - a nawet dostrzegała ten układ i starała się go rozbić [Marczewska-Rytko 2004, s. 258-259]. W broszurze wyborczej z 2005 r. A. Lepper pisał, że należy przeciwstawić się wszechogarniającemu złu i „wyrwać z korzeniami chwasty liberalizmu, korupcji i dekadencji, aby na powrót w to miejsce zasiać czyste ziarno uczciwości, wrażliwości społecznej i patriotyzmu dla dobra obecnych i przyszłych pokoleń Polaków" [Partie i ich programy... 2006, s. 301].

Kolejną ważną cechą apelu populistycznego jest idealizacja pewnych grup społecznych. P. Kozłowski twierdzi, że w rozumieniu populisty podstawą demokracji jest „prosty człowiek” - rządy powinny być „,W rękach prostych ludzi” ([Kozłowski 1995, s. 115] za: [Marczewska-Rytko 2004]). Populizm ponadto nie odwołuje się do intelektu, do wiedzy, ale do takich pojęć, jak sprawiedliwość, tradycja, uczucie czy też wiara. Z tego względu świat intelektu jawi się jako świat całkowicie obcy ogółowi społeczeństwa. Bardzo często wyrażana jest - o czym już wspominano - nieufność wobec profesjonalnych polityków [Marczewska-Rytko 2004, s. 262]. Obrazuje to jedna z wypowiedzi A. Leppera: „Od dziesięciu lat, a datą rozpoczynającą ten okres jest niewątpliwie zmowa przy okrągłym stole, dosadniej określana zmową przy okrągłym żłobie, neoliberalne, rządzące krajem elity postanowiły stać się akwizytorami obcych interesów, m.in. poprzez przyjęcie i realizowanie długofalowych interesów obcych gospodarek [...]. Tyle wolności, ile własności. Dlatego nie tylko mamy obowiązek dbać o naszą własność, ale także musimy pognać w diabły wszystkich, którzy chcą ją nam odebrać. Polska, nie mając własności, skaże się trwale i definitywnie na uzależnienie" [Samoobrona narodu... 2000]. 
Samoobrona RP wskazywała konkretnych wrogów. Byli to przede wszystkim liberałowie i architekci polskiej transformacji. Uosobieniem wszelkich nieszczęść Polski był L. Balcerowicz, pojmowany nie jako konkretna osoba, ale reprezentant wartości i elit, z którymi walczyła partia A. Leppera: „To nie jest moja prywatna wojna z Balcerowiczem, co chcą wmówić społeczeństwu środki masowego przekazu. [...] To jest konsekwentna praca dla naprawy Rzeczypospolitej w taki sposób, aby złe prawo zastąpić prawem dobrym i aby nie można było już nigdy w przyszłości podzielić Polski na Polaków Balcerowicza wykonujących swój nieodwołalny mandat $\mathrm{z}$ woli oligarchii finansowej i na Polaków rządzących z woli wyborców" [Przemówienia Przewodniczacego... 2003]. Co więcej, zdaniem Leppera Balcerowicz i inni czołowi polscy ekonomiści wykształceni na Zachodzie byli spolegliwi i podatni na naciski z zagranicznych ośrodków wpływu, gdyż spłacali długi instytucjom finansowym, które ich wykształciły [Lepper 2002].

Postrzeganie elit przeniosło się na relacje „my i oni”. Owi „oni” byli synonimem wszelkiego zła i zepsucia: „Wszystkie partie/koalicje walczyły dotąd o dostęp do prywatyzowanego majątku oraz dostęp do korzyści - łapówek - od zagranicznych inwestorów. W tym sensie wszystkie te partie/koalicje działały na rzecz zagranicznych interesów, gdyż sprzeciwienie się tym interesom oznaczało groźbę odcięcia od strumienia korzyści materialnych" [Poznański 2005]. Ta dychotomia „my i oni” podkreślana była przez populistycznych polityków, którzy szczególnie chętnie przywoływali mity oparte na resentymencie, zawierające dużą dozę wykluczenia i odwetu, tym samym potęgując społeczny strach, zamiast go opanowywać [Nalewajko 2010, s. 234]. V. Tismaneanu stwierdza, że Polacy używają swojej historii w kategoriach „honoru” przeciwstawianego „hańbie” (za: [Nalewajko 2010, s. 236]), co bardzo czytelne było zwłaszcza w apelu Samoobrony RP.

Jak już wspomniano, w ugrupowaniach o charakterze populistycznym niezmiernie ważną rolę odgrywa lider. Tego typu przywództwo bezsprzecznie reprezentował A. Lepper. Widać to było przede wszystkim w sposobie działania Samoobrony jako partii politycznej, związku zawodowego czy ruchu społecznego. Uwidaczniało się to także na przykładzie strony internetowej Samoobrony - sporą część jej zasobów stanowiły dokumenty i wypowiedzi sygnowane przez A. Leppera czy też jemu dedykowane. Polityk jawił się w nich jako trybun ludu. Badacze funkcjonowania struktur organizacyjnych Samoobrony Rzeczypospolitej Polskiej podkreślają także, że mimo iż jej statut dekretował, że przywództwo w partii cechuje się demokratyzmem, a organy kolegialne mają bardzo szerokie kompetencje, zaś przewodniczący jest przede wszystkim wykonawcą decyzji rady krajowej, to w praktyce wyglądało to zgoła inaczej. Bez większych wątpliwości można zatem uznać, że przywództwo w Samoobronie RP za czasów A. Leppera było autorytarne i miało mało wspólnego z deklarowaną demokracją [Drelich 
2006, s. 103]. W Samoobronie RP kongres był bowiem organem o charakterze rytualnym. Realnie odgrywał bardzo nieznaczną rolę. Można postawić tezę, że jego zadaniem było przede wszystkim legitymizowanie działań innych organów partii, a także udział w kreowaniu wizerunku ugrupowania poprzez przekaz medialny, jaki towarzyszy na ogół tego rodzaju wydarzeniom partyjnym [Kosowska-Gąstoł 2010, s. 160]. Ponadto zgodnie z przeprowadzonymi badaniami w samej Samoobronie RP aż 75\% respondentów uważało, że członkowie nie posiadają żadnej kontroli nad polityką prowadzoną przez lidera, a aż 89,5\% zgadzało się ze stwierdzeniem, że w partii liczą się tylko liderzy, a nie członkowie [Kosowska-Gąstoł 2010, s. 162].

Według kryterium zaproponowanego przez J. Burnsa przywództwo A. Leppera należy określić jako transakcyjne, to jest takie, w którym relacje pomiędzy liderami a zwolennikami bazują na transakcji - ,przywódca zachęca zwolenników do określonych zachowań, oferując coś w zamian". Warte podkreślenia jest to, że badacze dostrzegają w działalności A. Leppera również cechy przywództwa charyzmatycznego, opartego na działaniach pozainstytucjonalnych, co jest zjawiskiem stosunkowo rzadkim w demokracjach. Analiza wystąpień oraz publikacji A. Leppera skłania dodatkowo do stwierdzenia, iż „oferowanym wyborcom towarem” nie były tylko doraźne obietnice kierowane głównie do środowisk wiejskich, ale pewna szersza perspektywa zmian systemowych [Kasińska-Metryka 2006, s. 147].

Eklektyzm programowy Samoobrony RP podkreśla także W. Gałkiewicz. Badaczka twierdzi ponadto, że była to „poniekąd partia klasowa, chłopska” [Gałkiewicz 2000a, s. 53] i jedna z najbardziej populistycznych i roszczeniowych partii na scenie politycznej kraju [Gałkiewicz 2000b, s. 149]. Samoobrona RP prezentowała się w dokumentach programowych jako ugrupowanie ludowo-narodowe, ekologiczne i pro-socjalne - reprezentujące interesy całej gospodarki narodowej, w tym zwłaszcza obszary związane z rolnictwem [Samoobrona narodu... 2000]. Wszystko to dosyć wyraźnie klasyfikuje analizowane ugrupowanie jako populistyczne.

Także w literaturze zachodniej można było spotykać tego typu charakterystykę Samoobrony RP. Czasem wręcz określana była mianem partii ekstremalnie populistycznej o zabarwieniu lewicowym [Owen i Tucker 2010, s. 30]. Niejako na marginesie należy w tym miejscu dodać, że znawcy przedmiotu podkreślają różnice pomiędzy populizmem zachodnioeuropejskim a populizmem w krajach postkomunistycznej Europy. R. Markowski wskazuje na kilka podstawowych różnic przesądzających o odmiennościach wschodnio- i zachodnioeuropejskiego populizmu. Pierwsza to stosunek do państwa. W krajach postsocjalistycznych antypaństwowość oznacza bunt przeciw elitom władzy i pieniądza połączony z roszczeniami wobec państwa, od którego oczekuje się, że zaprowadzi porządek i przywróci sprawiedliwość, odbierając bogatym to, co w nieuczciwy sposób zagar- 
nęli. W krajach Europy Zachodniej populizm stanowi przede wszystkim reakcję na kryzys państwa dobrobytu i jego politykę redystrybucji. Jest to również efekt rozczarowania praktyką demokracji, podczas gdy w Europie Środkowo-Wschodniej populizm jest odpowiedzią na niedostatki wynikające ze zbyt krótkiego stażu demokracji. Markowski zwraca też uwagę na „przekrój stratyfikacyjny” obu typów populizmu. W krajach zachodnich trudno jednoznacznie wskazać kontury klasowe ugrupowań populistycznych, natomiast w Europie Środkowo-Wschodniej partie te popierane są głównie przez osoby pozbawione pracy bądź zagrożone jej utratą, źle sytuowane i słabo wykształcone. W obu przypadkach istotną rolę odgrywają kwestie etniczne. Bezsprzecznie jednak analizowane typy populizmu mają odmienne źródła. W Europie Zachodniej dominuje ksenofobiczny aspekt populizmu, będący pochodną doświadczanych na co dzień problemów masowej imigracji. W społeczeństwach postsocjalistycznych przewagę ma nacjonalistyczny wariant populizmu, który znajduje często wyraz w hasłach solidaryzmu narodowego i w spiskowej teorii dziejów, wymierzonych przeciw mniejszościom narodowym zamieszkującym terytorium danego państwa bądź występujących w interesie diaspory w krajach ościennych [Markowski 2004, s. 23-24].

\section{Ugrupowanie antysystemowe czy partia protestu?}

Mianem partii antysystemowych R. Herbut określa te ugrupowania, które podejmują różnorakie działania nastawione na podważenie czy też osłabienie legitymacji systemu demokratycznego [Herbut 2002, s. 133]. Takie zamiary można było zauważyć w działalności partii A. Leppera, kiedy twierdził np.: „Cały ten okrągło-stołowy układ polityczny zaważył w nieszczęsny sposób na samym początku przemian dokonywających się w Polsce. Zaważył wysoce negatywnie, bo nie był wyrazem jakiejś autentycznej woli narodu, ale po prostu międzynarodowego, tajnego porozumienia, żeby nie powiedzieć - spisku" [Lepper i Ul 1993, s. 26]. Herbut jednak doprecyzowuje, że można mówić o dwóch podejściach do kategorii antysystemowości. Przede wszystkim kwalifikator ,antysystemowa” (partia) może być traktowany w sposób mocny. Chodziłoby wówczas o ugrupowania, których postulaty i zachowania mają wyraźnie delegitymizujący charakter wobec demokratycznego systemu politycznego. Tego typu partiami byłyby np. ugrupowania komunistyczne czy lewackie (szczególnie przed 1989 r.), wyraźnie podważające legitymację społeczną demokracji jako takiej. Innym rodzajem antysystemowości jest natomiast kwestionowanie przez określone partie nie tyle demokratycznego porządku społecznego jako takiego, ile pewnych zasad gry politycznej, związanych przede wszystkim z funkcjonowaniem systemu partyjnego. Tego typu partie można określić mianem partii protestu, partii antykonsensualnych. Bardzo 
często łączy je fakt, że są to ugrupowania relatywnie młode, nieduże i szukające swego miejsca w ramach toczących się przetargów politycznych. Często operują one hasłami o charakterze populistycznym, chcąc w ten sposób „przeniknąć” do głównego nurtu dyskusji społecznej, i „mówią” potencjalnym odbiorcom to, co ci chcą usłyszeć. Partie protestu - mimo dosyć daleko posuniętych postulatów - nie kwestionują założeń demokratycznego systemu politycznego. Przynależność do tej strefy może okazać się ponadto fenomenem przejściowym i partie początkowo tam sytuowane mogą zostać wchłonięte w ramach przetargów politycznych [Herbut 2002, s. 134-136]. Powyższe rozróżnienie należy mieć na uwadze, gdy napotyka się w literaturze przedmiotu - jak np. u P. Grzelaka [2002, s. 117] - na określenia Samoobrony RP jako partii jednoznacznie opozycyjnej, antysystemowej.

Jeśli uważnie prześledzi się historię, przeanalizuje dokumenty programowe oraz wypowiedzi liderów Samoobrony RP, okaże się, iż w dużym stopniu pasować będzie ona do kategorii partii protestu, a nie antysystemowej. Praktycznie nie kwestionowała ona bowiem zasadności funkcjonowania ustroju demokratycznego. Oczywiście odmawiała elitom politycznym Polski legitymacji do sprawowania władzy, ale nie było to kwestionowanie samych zasad demokracji, a jedynie mandatu społecznego partii sprawujących władzę. Bardzo szybko także Samoobrona RP zaczęła wykorzystywać mechanizmy funkcjonowania demokracji dla własnych potrzeb, m.in. wystawiając swoich przedstawicieli w wyborach. Założenia programowe Ruchu Samoobrona z 1993 r. w kwestiach ustrojowych brzmiały następująco: „Za podstawę ustroju politycznego przyjmujemy demokrację, dostosowaną do współczesnych warunków społecznych i cywilizacyjnych" [Lepper i Ul 1993, s. 129]. Polska miała być także demokracją parlamentarną z jednoizbowym parlamentem i prezydentem pochodzącym z wyborów powszechnych [Lepper i Ul 1993, s. 130].

„Termin »polityka protestu « zazwyczaj oznacza umyślne zastosowanie publicznej formy protestu przez ugrupowanie i organizację (rzadziej przez pojedyncze osoby), którego celem jest wywarcie wpływu na decyzję lub proces polityczny, niosące w odczuciu protestujących negatywne konsekwencje dla nich, innej grupy bądź całego społeczeństwa” [Rucht 2010, s. 349]. „Protest stał się »normalną《 częścią polityki. Według Światowego Badania Wartości (World Values Survey) przeprowadzonego w latach 1999-2002 udział w różnych formach protestu wykazywał tendencję wyższą w dojrzałych demokracjach zachodnich i innych, zarówno w porównaniu z młodymi demokracjami z Europy Środkowo-Wschodniej, jak i ze stojącymi na »niższym szczeblu rozwoju« krajami półkuli południowej" [Rucht 2010, s. 357].

Warto za J. Dzwończyk zwrócić uwagę na swego rodzaju ewolucję Samoobrony RP. Na początku lat 90 . XX w. reprezentowała ona przede wszystkim „nurt agrarny populizmu", który odwoływał się do demokracji populistycznej o znamio- 
nach anarchistycznych. Jej celami było wówczas oddłużenie rolnictwa, następnie zaś całej gospodarki, i zaprzestania importu żywności i zboża. Działania jej polegały na akcjach odmowy płacenia podatków - Samoobrona RP tworzyła „brygady antyegzekucyjne", które zastraszały egzekutorów, a nawet siłą przeciwdziałały licytacjom zadłużonych gospodarstw. Z biegiem lat zaczęła odwoływać się do wszystkich niezadowolonych grup społecznych i przekształciła się w ugrupowanie reprezentujące polską odmianę ,populizmu protestu”, które nie zapomina o swych plebejskich korzeniach, czego wyrazem miało być stwierdzenie A. Leppera po sukcesie wyborczym w 2001 r.: „Wersal skończył się w dniu, w którym Samoobrona weszła do sejmu" [Dzwończyk 2005, s. 300].

J. Flis [2009, s. 161], analizując pojawienie się Samoobrony RP w parlamencie w 2001 r., określił ją jako nowe zjawisko polskiej sceny politycznej: „ruch radykalnego, antysystemowego buntu, skierowanego przeciwko establishmentowi. Buntu, który w opinii wielu był wspierany przez opozycyjny SLD jako sposób na osłabienie AWS, ale był też odzwierciedleniem autentycznych nastrojów społecznych i radykalizacji w istotnych obszarach kraju". Poparcie dla Samoobrony RP wynikało z postrzegania przez jej elektorat wielkomiejskiego establishmentu, w tym mediów, jako beneficjentów zmian i korzyści, z których oni sami zostali wykluczeni.

Po kolejnym sukcesie wyborczym z 2005 r. partia A. Leppera przeszła dalszą metamorfozę, stając się ugrupowaniem rządzącym. Prawdopodobnie ta szybka zmiana wizerunku partii z początkowo antysystemowej - następnie partii protestu - na partię sprawującą władzę sprawiła, że Samoobrona RP utraciła poparcie i zniknęła z parlamentu. Zjawiska te zaszły równocześnie z poprawą sytuacji gospodarczej po wejściu Polski do UE oraz z informacjami o domniemanych aferach, w które zaangażowani mieli być czołowi politycy Samoobrony $\mathrm{RP}$, co implikowało, iż propagowane przez nich hasła moralności straciły sens. S. Drelich twierdzi, że w ogóle sukcesy wyborcze Samoobrony RP należy wiązać z podbudową ideologiczną - przedstawianiem tej partii jako ugrupowania protestu. Kryzysy polityczne I, III i IV kadencji parlamentu spowodowały wzrost poziomu relewancji ugrupowań małych i średnich, które miały duże możliwości stosowania politycznego szantażu w stosunku do układu rządowego. Z czasem partia A. Leppera została wchłonięta w system przetargów politycznych i stała się jego stałym elementem, przez co coraz bardziej oddalała się od postulatów, których podniesienie przyczyniło się do jej sukcesu. Stąd na podstawie doświadczeń ostatnich lat trudno bronić tezy o antysystemowości [mocnej - przyp. R.L.] Samoobrony RP [Drelich 2006, s. 102]. Zwłaszcza iż przedstawiciele tej partii już w momencie wchodzenia w koalicję rządową z PiS i LPR deklarowali, że idą na kompromisy i prezentowanego w kampanii wyborczej programu nie są w stanie zrealizować [Wystapienie Janusza Maksymiuka... 2006]. 
Określanie Samoobrony RP mianem partii protestu potwierdzają przytaczane przez R. Markowskiego badania exit-pollowe PBS, które wskazują np., że wśród elektoratu tego ugrupowania w 2001 r. zaledwie 12\% nie brało udziału w wyborach w 1997 r. 10\% głosów poparcia dla Samoobrony RP prawie w całości pojawiło się dopiero w ostatnich wyborach, a oznaczać to miało tylko tyle, że w zdecydowanej większości byli to obywatele będący uprzednio zwolennikami innych partii [Markowski i Cześnik 2002, s. 24], co implikuje, iż byli rozczarowani dotychczasowymi politykami i jakością polityki. Dodatkowo za tezą, że Samoobrona RP wykazywała cechy typowe dla populistycznej partii protestu, zdają się świadczyć przytaczane przez wspomnianego P. Grzelaka badania socjologiczne, zgodnie z którymi w 2001 r. zaobserwowano interesujące podobieństwo opinii ekonomicznych osób głosujących na Samoobronę RP i niegłosujących [Grzelak 2002, s. 232]. Wskazuje to na fakt, iż opinie elektoratu Samoobrony RP, określanego bardzo często jako tego, który został zepchnięty w wyniku reform na margines życia społeczno-gospodarczego [Jasiewicz 2002, s. 98], były zbieżne z opiniami ludzi często rozczarowanych polityką i swoją niechęć do polityków przejawiających w odmowie udziału w wyborach.

K. Gorlach twierdzi, że przypadek Samoobrony RP pokazuje krótkotrwałą popularność partii kierowanej przez bardzo wyrazistego lidera, uwikłanej w konflikty i protesty, cieszącej się znaczącym poparciem wyłącznie w okresie najbardziej skumulowanych konfliktów politycznych i wystąpień. Badacz opiera się na analizach, które potwierdzają opinię o tymczasowości sukcesu Samoobrony RP jako populistycznej partii protestu, która wykorzystała kryzysowe lata rozwoju polskiej demokracji. Wchodząc w system bieżących przetargów politycznych i stając się jego częścią, straciła reputację partii protestu walczącej z domniemanym spiskiem elit. K. Gorlach [2010, s. 97-98] podaje następujące dane: rolnicy, wskazując w 1994 r. na organizacje broniące ich interesów, w 7,6\% opowiadali się za PSL, a tylko w 0,6\% za Samoobroną RP; w 1999 r. na PSL wskazywało 9,1\%, a na Samoobronę RP 27\%. W 2007 r. te dane wyglądały następująco: PSL - 4,5\%, Samoobrona RP - 2,7\%.

Bardzo dobrą charakterystykę Samoobrony RP jako partii sporządził M. Piskorski, który opowiadał się za usytuowaniem partii A. Leppera w zaproponowanej przez P. Lucardie kategorii prolokutorskiej partii protestu, która „podejmuje próbę artykulacji określonych interesów bez powoływania się na określoną ideologię" ([Lucardie 2000, s. 176] za: [Piskorski 2010b]). Ugrupowania tego typu budują bowiem swój apel polityczny przede wszystkim na podstawie roszczeń i postulatów najsłabszych grup społecznych, przy czym są pozbawione jednoznacznych preferencji o charakterze ideologicznym i wręcz unikają udziału w sporach o charakterze światopoglądowym. P. Lucardie podkreślał też epizodyczny charakter ich roli w ustabilizowanych systemach partyjnych - nierzadko 
rozpadają się tuż po wprowadzeniu w obszar debaty publicznej interesów bądź problemów danej grupy społecznej albo nawet nie są w stanie dotrwać do tego momentu. Czasem próbują przetrwać dłuższy okres poprzez poszerzenie oferty programowej o nowe elementy, stosując charakterystyczny konglomerat idei [Piskorski 2010a, s. 388-389]. Samoobrona RP prezentowała bezideologiczne oblicze, co pozwalało jej bardzo szybko zmieniać stanowisko w wielu kwestiach [Jasiewicz 2008, s. 7].

\section{Agraryzm Samoobrony}

Partią agrarną można najogólniej określić to ugrupowanie, które reprezentuje interesy rolników. Agraryzm może być definiowany jako „doktryna społeczno-polityczna oparta na zasadach solidaryzmu klasowego, organicyzmu i jedności moralnej chłopstwa, postulująca ewolucyjną przebudowę ustroju społeczno-gospodarczego w kierunku »trzeciej drogi« (pomiędzy kapitalizmem a socjalizmem)" [Leksykon politologii... 2004, s. 12], która w szczególny sposób uwzględniałaby interesy rolników i znajdowałaby się pod kierownictwem politycznym klasy chłopskiej. Agraryzm nawołuje także do „odrodzenia moralnego, duchowego i gospodarczego klasy chłopskiej i całego narodu" [Leksykon politologii... 2004, s. 12]. Partie agrarne nie mieszczą się w klasycznych biegunach rywalizacji (rodzinach partii) [Antoszewski i Herbut 2006, s. 104].

Odpowiedź na pytanie, czy Samoobrona jest partią agrarną, mimo pozornej prostoty nie jest łatwa. Bez wątpienia ma ona rodowód chłopski. W. Gałkiewicz [2000a, s. 53] określa ją jako klasową partię chłopską. J. Dzwończyk [1999, s. 92], pisząc jeszcze o Przymierzu „Samoobrona”, określała je jako nurt agrarny populizmu odwołujący się do demokracji populistycznej o znamionach anarchistycznych. Dodawała także, że Samoobrona RP, będąc ugrupowaniem o chłopskim rodowodzie, miała ambicje globalne - uznawała się za reprezentanta nie tylko rolników, ale wszystkich wyzyskiwanych i pokrzywdzonych przez arogancję elit [Dzwończyk 1999, s. 127]. Samoobrona RP często odwoływała się do swoich chłopskich korzeni i romantycznej wizji rolnictwa:, ,[...] to właśnie ta Polska żyjąca »pod strzechą" pozostała wierna polskim obyczajom, ojczystemu językowi i ojczystej wierze, wytworzyła fundamenty ludowej kultury, która do dzisiaj stanowi podstawę ogólnej kultury narodowej” [Brońmy swego... 2011].

W programach Samoobrony RP można znaleźć bliskie agraryzmowi wątki ekologizmu, podkreślane są związki człowieka (szczególnie chłopów) z przyrodą. W ogólnych postulatach ideowo-programowych zawarto m.in. ten, że stosunek człowieka z naturą, przyrodą i otaczającym go bezpośrednio środowiskiem powinny charakteryzować ład i harmonia. Należy wprowadzać w życie społeczne 
zasady ekologii, w tym tzw. ekologii ludzkiej - zasady harmonii współżycia w środowiskach społecznych oraz oczyszczanie z patologii tego środowiska. Partia postulowała likwidację Narodowego i Wojewódzkich Funduszy Ochrony Środowiska i Gospodarki Wodnej, a także innych funduszy celowych, w czym upatrywała ogromnych oszczędności budżetowych. W odezwie „Polska żywność - zdrowa żywność" nawoływała do bojkotu zagranicznej żywności i promowania zdrowej i ekologicznej polskiej produkcji rolniczej [Tomaszewski 2007, s. 176].

M. Piskorski stwierdza, że kwestią sporną jest istnienie inspiracji i podobieństw programowych pomiędzy Samoobroną RP a szeroko rozumianym polskim ruchem ludowym, na czele z jego współczesną emanacją w postaci Polskiego Stronnictwa Ludowego. To, co jest u nich wspólne, to częste odwoływanie się do społecznej nauki Kościoła oraz neoagraryzmu - jako poszukiwanie trzeciej drogi rozwoju społeczno-gospodarczego [Piskorski 2010a, s. 109]. Nie sposób natomiast określać Samoobrony RP mianem ugrupowania klasowego, reprezentującego wyłącznie interesy ludności rolniczej, gdyż jej apel wyborczy skierowany był także do innych grup społecznych [Piskorski 2006, s. 189]. Jak podkreślał A. Lepper, Samoobrona RP swój apel kierowała przede wszystkim do „zdezorientowanej, zmaltretowanej i niezorganizowanej jeszcze inteligencji, głównie zaś do polskich rolników, chłopów, do patriotycznego polskiego ludu, do światłych kręgów robotniczych, do polskiej młodzieży i do wszystkich, w których piersiach biją polskie serca" [Lepper 1999]. Biorąc jednak pod uwagę kryterium orientacji rozwojowej, partia ta głosiła postulaty zbliżone do prawicowej orientacji ,,agrarnej” [Piskorski 2006, s. 187]. Wysuwała pomysły stworzenia nowego ugrupowania: „Ruch społeczno-zawodowy i polityczny, jakim stała się w ostatnich latach Samoobrona, stawia obecnie postulat utworzenia [...] »bloku ludowo-narodowego«" [Brońmy swego... 2011]. Program pozytywny ugrupowania sprowadzał się do obietnic promowania trzeciej drogi, oznaczającej próby budowania nowego ładu w ramach drogi pośredniej między systemem kapitalistycznym a komunistycznym [Marczewska-Rytko 2004, s. 264], co jest bliskie agraryzmowi.

J. Staniszkis [2001, s. 20] stawiała retoryczne pytanie: „czy Lepper nie jest przypadkiem reprezentantem polskiej klasy średniej, tak ułomnej i karykaturalnej, jak karykaturalny i niepełny (bo pozbawiony struktur akumulacji) jest u nas kapitalizm?". Badaczka wskazywała na 200 tys. małych firm, które w 2001 r. były na granicy bankructwa, jako na potencjalnych wyborców Samoobrony RP ([Staniszkis 2001, s. 20] za: [Stępień 2006, s. 156]).

Analiza dokumentów programowych - zwłaszcza po 2000 r. - wskazuje wyraźnie, że Samoobrona RP miała ambicje reprezentowania całego społeczeństwa. Jej program społeczno-gospodarczy z 2003 r. zawierał propozycje adresowane do ogółu społeczeństwa i obejmował większość spraw związanych z polityką wewnętrzną (w tym dotyczącą wielu sektorów gospodarczych) oraz zewnętrzną 
państwa. Jeszcze w 1993 r. Lepper twierdził bowiem: „to, że trafiamy dziś łatwiej także do środowisk robotniczych i wielkoprzemysłowych, nie jest naszą słabością i błędem, ale siłą i potwierdzeniem słuszności obranej raz drogi" [Lepper i U1 1993, s. 29]. Można zatem stwierdzić, że Samoobrona RP mimo licznych (szczególnie w początkowym okresie swego istnienia) nawiązań do agraryzmu, nie była klasyczną partią tego nurtu. Używała bardzo często do swych celów retoryki agrarnej, jednak w jej programie wątki tej ideologii były tylko jedną z części składowych. Po wejściu w koalicję z Prawem i Sprawiedliwością oraz Ligą Polskich Rodzin działacze Samoobrony RP podjęli się kierowania resortem rolnictwa, ale także ministerstwami odległymi od spraw rolniczych, a bardzo newralgicznymi budownictwa oraz pracy i polityki społecznej. Co więcej, zapowiadano realizację w tych obszarach bardzo ambitnych prospołecznych planów [Lepper 2006].

\section{Podsumowanie}

Samoobrona Rzeczpospolitej Polskiej to ugrupowanie bardzo charakterystyczne na polskiej scenie politycznej. Jej działalność, sukcesy i porażki są odzwierciedleniem stanu polskiego systemu politycznego, który wciąż jest w fazie budowy.

Samoobrona RP stanowi przede wszystkim przykład populistycznej partii protestu, która nie poddaje się klasycznej typologizacji partii politycznych. Populizm jest najważniejszą cechą charakterystyczną tej partii i to on decydował zarówno o jej sukcesach, jak i porażkach. Bazowanie na nastrojach społecznych i specyficzny sposób działania na scenie politycznej sprawiało, że Samoobrona RP nie stworzyła kompleksowego i w miarę spójnego programu politycznego. Nie da się także jednoznacznie przyporządkować jej działalności i koncepcji programowych do znanych nurtów myśli politycznej. W miarę potrzeb Samoobrona RP czerpała z dorobku co najmniej kilku doktryn politycznych. Co więcej, była w stanie szybko zmieniać swoje oblicze ideologiczne i programowe.

\section{Literatura}

Antoszewski A. [2002], Ewolucja polskiego systemu partyjnego [w:] Demokratyzacja w III Rzeczpospolitej, red. A. Antoszewski, Wydawnictwo Uniwersytetu Wrocławskiego, Wrocław.

Antoszewski A. [2008], Partie i systemy partyjne państw Unii Europejskiej na przełomie wieków, Wydawnictwo Adam Marszałek, Torun.

Antoszewski A., Herbut R. [2006], Systemy polityczne współczesnej Europy, Wydawnictwo Naukowe PWN, Warszawa. 
Brońmy swego [2011], http://www.samoobrona.org.pl/pages/02.Partia/02.Program/index. php?document=05.bronmy.html (dostęp: 24.12.2011).

Drelich S. [2006], Analiza marketingowa kampanii parlamentarnej Samoobrony [w:] Wybory parlamentarne 2005. Analiza marketingowa, red. M. Jeziński, Wydawnictwo Adam Marszałek, Toruń.

Dzwończyk J. [1999], Populistyczne tendencje w społeczeństwie postsocjalistycznym (na przykładzie Polski), Wydawnictwo Adam Marszałek, Torun.

Dzwończyk J. [2005], Populizm jako strategia działania polskich partii politycznych [w:] Partie polityczne: permanentne problemy, red. J. Kornaś, Kieleckie Towarzystwo Edukacji Ekonomicznej, Kielce.

Dzwończyk J. [2006], Populizm jako czynnik blokujący rozwój społeczeństwa obywatelskiego w Polsce [w:] Populizm na przełomie XX i XXI wieku. Panaceum czy pułapka dla współczesnych społeczeństw?, red. M. Marczewska-Rytko, Wydawnictwo Adam Marszałek, Toruń.

Fedyszak-Radziejowska B. [2005], Bez większych szans na prezydenta, „Rzeczpospolita”, 13.IV.

Flis J. [2009], Polski system partyjny 1989-2009 [w:] Rzeczpospolita 1989-2009. Zwykte państwo Polaków?, red. J. Kleczkowski, Ośrodek Myśli Politycznej, Kraków.

Gałkiewicz W. [2000a], Partia Przymierze „Samoobrona” Rzeczypospolitej [w:] Partie i koalicje polityczne III Rzeczypospolitej, red. K.A. Paszkiewicz, Wydawnictwo Uniwersytetu Wrocławskiego, Wrocław.

Gałkiewicz W. [2000b], Samoobrona Rzeczypospolitej Polskiej [w:] Partie i koalicje polityczne III Rzeczypospolitej, red. K.A. Paszkiewicz, Wydawnictwo Uniwersytetu Wrocławskiego, Wrocław.

Gorlach K. [2010], Razem, ale osobno - przyczynek do koncepcji rozwarstwienia klasowego chłopstwa [w:] Kulturowe aspekty struktury społecznej. Fundamenty, konstrukcje, fasady, red. P. Gliński, I. Sadowski, A. Zawistowska, Wydawnictwo IFiS PAN, Warszawa.

Grzelak P. [2002], Głosowanie ekonomiczne w Polsce w 2001 roku w warunkach dezintegracji ugrupowań rzadzacych, ,Studia Polityczne”, nr 13.

Gwiazda A. [2008], The Parliamentary Election in Poland, October 2007, „Electoral Studies", nr 27.

Herbut R. [2002], Teoria i praktyka funkcjonowania partii politycznych, Wydawnictwo Uniwersytetu Wrocławskiego, Wrocław.

Jasiewicz K. [2002], Portfel czy różaniec? Wzory zachowań wyborczych Polaków w latach 1995-2001 [w:] System partyjny i zachowania wyborcze. Dekada polskich doświadczeń, red. R. Markowski, Instytut Studiów Politycznych Polskiej Akademii Nauk, Fundacja im. Friedricha Eberta, Warszawa.

Jasiewicz K. [2008], The New Populism in Poland. The Usual Suspects?, „Problems of Post-Communism", nr 3.

Kasińska-Metryka A. [2006], Populizm w warunkach kształtującej się demokracjipułapka czy remedium? [w:] Populizm na przełomie XX $i$ XXI wieku. Panaceum czy pułapka dla współczesnych społeczeństw?, red. M. Marczewska-Rytko, Wydawnictwo Adam Marszałek, Toruń.

Kosowska-Gąstoł B. [2010], Struktury organizacyjne Polskiego Stronnictwa Ludowego oraz Samoobrony RP na tle teoretycznych modeli partii [w:] Partie chłopskie i ludowe w Polsce oraz Europie Środkowo-Wschodniej (1980-2009), red. J. Gmitruk, 
A. Indraszczyk, S. Stępka, Muzeum Historii Polskiego Ruchu Ludowego, Wydział Nauk Humanistycznych SGGW, Warszawa.

Kozłowski P. [1995], Szukanie sensu, czyli o naszej wielkiej zmianie, Wydawnictwo Naukowe PWN, Warszawa.

Leksykon politologii wraz z aneksem o reformie samorzadowej, wyborach do sejmu, prezydenckich oraz gabinetach rzadowych [2004], red. A. Antoszewski, R. Herbut, Atla 2, Wrocław.

Lepper A. [1999], Jakiej Polski chcemy?, http://www.samoobrona.org.pl/pages/07.Publikacje/06.Narodu/sn0/\#JAKIEJPOLSKICHCEMY (dostęp: 24.09.2013).

Lepper A. [2002], Lista Leppera, http://www.samoobrona.org.pl/pages/07.Publikacje/01. Listaleppera/07/ (dostęp: 15.10.2013).

Lepper A. [2006], Drodzy rodacy!, „Chłopska Droga”, 17 września.

Lepper A., U1 J. [1993], Samoobrona - dlaczego? Przed czym?, Agencja Wydawniczo-Prasowa „Wyraz”, Warszawa.

Lucardie P. [2000], Prophets, Purifiers and Prolocutors: Towards a Theory on the Emergence of New Parties, „Party Politics”, vol. 6, nr 2.

Marczewska-Rytko M. [2004], Samoobrona - wizerunek marketingowy czy populizm? [w:] Zrozumieć polityke. Główne problemy teorii polityki i współczesnej myśli politycznej, red. R. Bäcker, J. Marszałek-Kawa, J. Modrzyńska, Wydawnictwo Adam Marszałek, Toruń.

Markowski R. [2004], Populizm a demokracja: ujęcia, dylematy, kontrowersje [w:] Populizm a demokracja, red. R. Markowski, Instytut Studiów Politycznych PAN, Warszawa.

Markowski R., Cześnik M. [2002], System partyjny po wyborach 2001 roku: ciagłość czy zmiana?, „Studia Polityczne”, nr 13.

Migalski M. [2008], Czeski i polski system partyjny. Analiza porównawcza, Wydawnictwo Sejmowe, Warszawa.

Miliard F. [2007], The 2005 Parliamentary and Presidential Elections in Poland, „Electoral Studies", nr 26.

Nalewajko E. [2010], Populizm w polskiej polityce [w:] Polacy równi i równiejsi, red. M. Jarosz, Instytut Studiów Politycznych PAN, Warszawa.

Owen A., Tucker J.A. [2010], Past is Still Present: Micro-level Comparisons of Conventional vs. Transitional Economic Voting in Three Polish Elections, „Electoral Studies", nr 29.

Partie i ich programy [2006], red. I. Słodkowska, M. Dołbakowska, Instytut Studiów Politycznych PAN, Warszawa.

Piskorski M. [2004a], Samoobrona RP - kim jesteśmy i o co walczymy, http://www.samoobrona.org.pl/pages/02.Opis/ (dostęp: 19.12.2011).

Piskorski M. [2004b], Samoobrona Rzeczypospolitej Polskiej [w:] Lokalne i krajowe struktury polskich partii politycznych, red. Ł. Tomczak, Centrum Doradztwa i Doskonalenia Nauczycieli w Szczecinie, Szczecin.

Piskorski M. [2006], Samoobrona Rzeczypospolitej Polskiej- między lewica a agraryzmem [w:] Partie i ugrupowania parlamentarne III RP, red. K. Kowalczyk, J. Sielski, Dom Wydawniczy Duet, Torun.

Piskorski M. [2010a], Elementy agraryzmu w Samoobronie Rzeczypospolitej Polskiej [w:] Ludowcy i problematyka agrarna na poczatku XXI wieku, red. Ł. Tomczak, Wydawnictwo Marina, Wrocław. 
Piskorski M. [2010b], Samoobrona RP w polskim systemie partyjnym, https://repozytorium.amu.edu.pl/jspui/bitstream/10593/766/1/DR.pdf (dostęp: 20.12.2011).

Poznański K. [2005], Kto trzyma władzę?, http://www.samoobrona.org.pl/pages/07. Pisza/00_ktotrzymawladze/ (dostęp: 14.10.2013).

Przemówienia Przewodniczacego Partii Samoobrona RP, Posła na Sejm RP Andrzeja Leppera w czasie IV Kadencji Sejmu RP [2003], http://www.samoobrona.org.pl/ pages/07.Publikacje/07.Przemowienia/ (dostęp: 22.08.2013).

Rucht D. [2010], Rosnace znaczenie polityki protestu [w:] Zachowania polityczne, t. 2, red. R.J. Dalton, H.D. Klingemann, red. nauk. wydania polskiego R. Markowski, tłum. A. Brzóska et al., Wydawnictwo Naukowe PWN, Warszawa.

Samoobrona narodu [2000], http://www.samoobrona.org.pl/pages/07.Publikacje/06. Narodu/sn4/\#4 (dostęp: 22.12.2012).

Staniszkis J. [2001], Demokracja w krzywym zwierciadle, „Gazeta Finansowa”, nr 43 (165).

Stanowisko Prezydium Partii Samoobrona RP w sprawie planowanych działań w kierunku zliberalizowania ustawy o planowaniu rodziny, ochrony płodu ludzkiego $i$ warunkach dopuszczalności przerywania ciaży oraz wprowadzenia w życie projektu ustawy o zwiąkach partnerskich [2003], „Chłopska Droga”, 30 listopada.

Stępień S. [2006], Populizm w programach wyborczych do parlamentu 2001 roku [w:] Populizm na przełomie XX $i$ XXI wieku. Panaceum czy pułapka dla współczesnych społeczeństw?, red. M. Marczewska-Rytko, Wydawnictwo Adam Marszałek, Torun.

Szawiel T. [2002], Podziat na lewice i prawice w Polsce po 1989 roku-jego sens i trwałość [w:] System partyjny i zachowania wyborcze. Dekada polskich doświadczeń, red. R. Markowski, Instytut Studiów Politycznych Polskiej Akademii Nauk, Fundacja im. Friedricha Eberta, Warszawa.

Tomaszewski M. [2007], Polityka ekologiczna w programach wyborczych partii politycznych. Analiza wyborów parlamentarnych 2005 roku [w:] Oblicza polskiego systemu politycznego, red. B. Krauz-Mozer, K. Sobolewska-Myślik, Wydawnictwo Adam Marszałek, Toruń.

Wystapienie Janusza Maksymiuka - wiceprzewodniczacego klubu parlamentarnego Samoobrony RP $w$ debacie nad expose premiera [2006], „Chłopska Droga”, 30 lipca.

\section{The Place of Samoobrona RP in the Typology of Political Parties}

Samoobrona RP (Self-Defence of the Republic of Poland), headed by its charismatic leader, Andrzej Lepper, was one of the most interesting parties on the Polish political scene throughout the first decade of the $21^{\text {st }}$ century. Its success and ultimate collapse can be attributed to the political situation in Poland, the party's unique political appeal and the way it conducted itself - all factors that make it difficult to classify the party. In this article the author shines a light on the fundamental problems concerning the typology of Samoobrona RP.

Keywords: Samoobrona RP (Self-Defence of the Republic of Poland), Andrzej Lepper, typology, political party, Polish political system, populism. 